\title{
Evidence of high genetic diversity and significant population structuring in Vachellia tortilis (Forsk.) Galasso \& Banfi population in Kenya
}

\author{
Stephen F. Omondi ${ }^{1}$ (D) Joseph Machua ${ }^{1}$ - Gabriel M. Muturi ${ }^{1}$ - John M. Gicheru ${ }^{1} \cdot$ So Hanaoka ${ }^{2}$
}

Received: 9 June 2018 / Accepted: 10 April 2019 / Published online: 30 April 2019

(C) INRA and Springer-Verlag France SAS, part of Springer Nature 2019

\begin{abstract}
- Key message High genetic diversity and significant population structure of Vachellia tortilis population in Kenya has been determined using nuclear microsatellite markers. Despite wide distribution and long-distance gene dispersal of the species, geographic barriers affect its gene flow patterns. The Gregorian Rift Valley that cuts across the country is suggested to have differentiated the populations into eastern and western clusters.

- Context Vachellia tortilis is an important dryland tree species valued for fuelwood and fodder production; however, no strategy has been put in place for sustainable management of the species genetic resources. Furthermore, there is inadequate information on the species population genetics to aid the development of such strategies.

- Aims We evaluated the amount and structure of neutral genetic diversity of V. tortilis population in Kenya and provided recommendations necessary for improvement and conservation of the species genetic resources. We hypothesized that the current genetic diversity of $V$. tortilis is high because of its demographic history and that no population structuring was expected to occur due to the presumed long-distance and effective gene flow patterns within the species.

- Methods Leaf tissues were collected from 15 putative natural populations of $V$. tortilis covering the whole distribution range in Kenya. DNA was isolated from the leaf tissues and analyzed using microsatellite markers. In total, 450 trees were genotyped using ten polymorphic nuclear microsatellite loci, and genetic diversity and population structure parameters were determined.

- Results We found high levels of genetic diversity within the populations with a mean gene diversity at 0.85 . However, significant population differentiation was evident $\left(F_{\mathrm{ST}}=0.026, P=0.007 ; R_{\mathrm{ST}}=0.032, P=0.004\right)$ despite a large number of migrants per generation $\left(N_{\mathrm{m}}=5.3\right)$. Population structure detected suggests the presence of two clusters, although many individuals showed mixed ancestry. The groups reflect the influence of geographic patterns and historical population gene flow.

- Conclusion There exists high genetic diversity in V. tortilis in Kenya with significant population structuring into two clusters. We recommend the consideration of the two distinct groups in the development of the species improvement, breeding, and conservation programs. Such programs should ensure maintenance of the majority of the extant genetic diversity.
\end{abstract}

Keywords Conservation strategy $\cdot$ Gene flow $\cdot$ Genetic structure $\cdot$ Nuclear microsatellites $\cdot$ Vachellia tortilis $\cdot$ Habitat disturbances

Handling Editor: Bruno Fady

Electronic supplementary material The online version of this article (https://doi.org/10.1007/s13595-019-0834-y) contains supplementary material, which is available to authorized users.

Stephen F. Omondi

stephenf.omondi@gmail.com

1 Kenya Forestry Research Institute, P.O. Box 20412-00200, Nairobi, Kenya

2 Forest Tree Breeding Center, Forestry and Forest Products Research Institute, Hitachi, Ibaraki 319-1301, Japan

\section{Introduction}

Vachellia tortilis (Forssk.) Galasso \& Banfi formally known as Acacia tortilis is a dryland tree species commonly referred to as the umbrella thorn tree (Andersen and Krzywinski 2007). The species is used to be found in the genus Acacia; however, it currently falls under the genus Vachellia in the subfamily Mimosoideae, in Fabaceae family. The genus Vachellia is recognized by the angiosperm phylogeny group (APG) III new classification, after the genus Acacia was segregated into five genera (Kyalangalilwa et al. 2013). The species is one of the approximately 135 Acacia species widely distributed in Africa 
including Madagascar, but it also occurs in the Middle East (Hines and Eckman 1993; Allen 2007; Andersen and Krzywinski 2007; Kennenni 2008; Kyalangalilwa et al. 2013). In Africa, $V$. tortilis occurs in the drier parts of the Sahel and extends all the way to South Africa and Madagascar (Le Floćh and Grouzis, 2003). The species is very distinctive and easily recognized, with the characteristic mixture of long straight spines and shorter hooked prickles combined with spirally twisted or contorted pods (Maundu and Tangnas 2005). Over most of its distribution ranges, the characteristically flattened crown of the adult tree has given it the popular name of "umbrella thorn". However, the species shows intricate bushy growth form in the young trees (Abdelrahman and Krzywinski 2008).

Morphologically, V. tortilis varies considerably, ranging from multistemmed shrubs to large trees measuring up to 20 $\mathrm{m}$ in height and is suggested to be differentiated into four subspecies: heteracantha, tortilis, raddiana, and spirocarpa (Luckow 2005). Earlier works suggest that only tortilis subspecies occur in Kenya; however, the subspecies have not been properly described in the country (Oballa P, personal communication). The species is highly drought tolerant with large ecological plasticity, colonizing areas with annual precipitation ranging from 40 to $1200 \mathrm{~mm}$ and having dry seasons of up to 12 months (Abdallah et al. 2008; El Ferchichi et al. 2009; Van Coillie et al. 2016). Because of its high tolerance to climatic stress, $V$. tortilis is suitable for rehabilitation of degraded sites (El Ferchichi et al. 2009).

In terms of its reproductive biology, $V$. tortilis is a hermaphrodite with white or pale yellowish-white flowers that are sessile or shortly pedicellate, scented, and mainly pollinated by insects such as bees, butterflies, and wasps (Tybirk 1993). The species is believed to be outcrossing and genetically selfincompatible with long-distance gene flow (Shrestha et al. 2002). Earlier works suggest that individual trees of $V$. tortilis have different contribution in terms of male or female gender expressions within a population (Tybirk 1993). In some places in Kenya, flowering occurs in two seasons before the start of the rains at the age of 5 years (Omondi et al. 2004). Seed dispersal is through gravity or propulsion from drying dehiscent pods; however, ungulates have been reported to enhance long-distance seed dispersal in the species (Orwa et al. 2009).

Vachellia tortilis is considered as a key tree species of the arid and semi-arid lands (ASALs) because of its multiple uses (Andersen and Krzywinski 2007). The prolific pods, which are high in protein (15-20\%), fall to the ground where they are eaten by both livestock and wildlife browsers (Orwa et al. 2009). The leaves, new shoots, and seedlings are also browsed, with leaves being available throughout most of the dry season when other fodder sources are scarce in the SaharaSahel Belt. Because they comprise much of the arboreal habitat, $V$. tortilis is also critically important sources of nesting habitat for native birds. Many pollinating insects are also dependent on the species, which provide a major source of pollen and nectar when in flowers. In Africa, $V$. tortilis is thus a classic example of keystone species, essential to the functioning of ecological community (Primack 1993; Andersen and Krzywinski 2007). The species influence not only the plant ecological community, but also the socioeconomic well-being of human populations living in these ecosystems (Berchem 1994; Hobbs et al. 2014). Gum produced by V. tortilis is edible, and the bark can be used to produce strong fiber. $V$. tortilis starts producing firewood at 8-18 years, at a rate of $50 \mathrm{~kg} /$ tree/year. Its fast growth and good coppicing ability, in addition to high calorific value of its wood (about 4400 $4900 \mathrm{kcal} / \mathrm{kg}$ ), make it well suited for use as firewood and charcoal production (Orwa et al. 2009).

Despite their ecological and socioeconomic significance, dryland ecosystems and the biodiversity therein continue to undergo unprecedented destructions and degradations through overexploitation of its vegetation (Whitmore 1997; Bawa and Seidler 1998; Lamb et al. 2005; United Nations Environment Management Group (UNEMG) 2011). Furthermore, limited information is available about the status of most species in these ecosystems. These uncertainties pose threats to biodiversity, biological processes, and human well-being within these ecosystems (Young et al. 1996; Roberts et al. 2009). The aforementioned disturbances have led to the loss of genetic diversity and localized extinction of some vegetation, thereby disrupting mutualisms of vegetation populations with agents of pollination and seed dispersal (Nason and Hamrick 1997; Aldrich PR Hamrick 1998; Dick 2001). In the face of these ecological dynamics, $V$. tortilis remains one of the only wild Acacia, which grows spontaneously in ASALs, making it an important species for conservation and socioeconomic development (Romdhane et al. 2006). However, little is known about the species' current genetic diversity and structure especially in Kenya where conservation and sustainable management strategy is under development. Population genetic information is essential for sustainable utilization of its genetic resources including genetic improvement and conservation.

Earlier studies of genetic variability of $V$. tortilis using various methods have suggested the presence of high genetic diversity; however, the discriminatory power of some of these methods is low compared to modern markers such as microsatellite. For example, studies by El Ayadi et al. (2011) and Wahbi et al. (2013) reported high genetic diversity; however, these conclusions depended on morphological characteristics that are easily influenced by environmental factors. Another study by El Ferchichi et al. (2009) relying on a combination of morphological characteristics, chromosome counts, and DNA content approach also reported high levels of genetic diversity 
and geographic structuring of $V$. tortilis population. Using morphological descriptions and randomly amplified polymorphic DNA (RAPD) molecular markers, Abdelrahman (2007) also reported high genetic diversity but with restricted gene flow among populations of $V$. tortilis complex. The study by Abdelrahman (2007), however, failed to show any significant differences among the three putative $V$. tortilis subtaxa, probably due to the inability of the molecular markers used to effectively estimate evolutionary parameters. Genetic diversity and population structure based on more polymorphic, discriminatory, and reproducible markers such as nuclear microsatellites have not been reported for $V$. tortilis. Recently, microsatellite markers have been isolated and characterized for $V$. tortilis (Winters et al. 2013; Omondi et al. 2015), which would provide more accurate genetic information than the ones already reported.

In this study, we investigated the genetic diversity and population structure of $V$. tortilis population in Kenya to guide the ongoing development of conservation and sustainable management strategy. We used highly variable and reproducible nuclear microsatellite markers that were developed and characterized for the species in Kenya (Omondi et al. 2015). Our study aimed at (i) characterizing the level of genetic diversity in $V$. tortilis, (ii) determining the distribution patterns of genetic diversity within and among the populations of the species in Kenya, and (iii) discussing possible implications of the generated population genetic data and providing suggestions for the species management and conservation. We hypothesized that there would be high genetic diversity and absence of population differentiation within the species due to its continuous distribution in the drylands and predominant outcrossing mating pattern.

\section{Materials and methods}

\subsection{Study area and sampling design}

Vachellia tortilis is widely distributed in Kenya, spreading from the coastal region all the way to western and northern regions covering an altitudinal range from 1 to $1800 \mathrm{~m}$ above sea level. We therefore used secondary data and field reconnaissance to delineate putative $V$. tortilis populations in Kenya. In this study, we defined a population as a group of trees separated from their nearest conspecifics by more than $10 \mathrm{~km}$. In total, we identified 15 putative populations of $V$. tortilis representing the entire distribution of the species in Kenya (Fig. 1). The minimum straight line distance between two populations was $37 \mathrm{~km}$ (Isiolo and Maua), while the maximum distance was $967 \mathrm{~km}$ (Voi and Lokichogio). The populations and their descriptions are shown in Table 2.

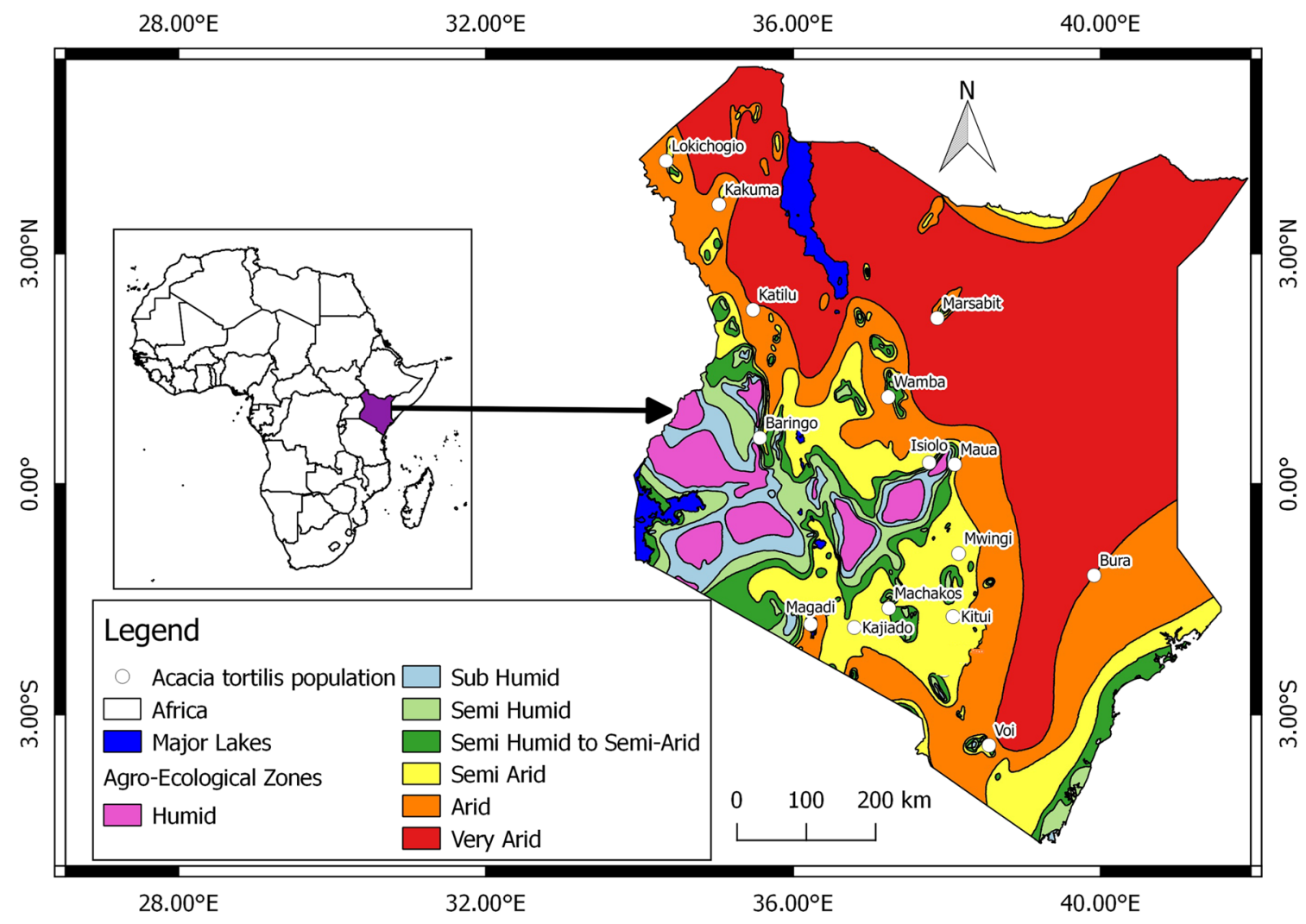

Fig. 1 Distribution of 15 natural populations of $V$. tortilis in Kenya 
From each population, we randomly sampled 30 individual trees at a distance of about $250 \mathrm{~m}$ apart to avoid sampling of genetically related trees. The sampled trees were mapped using a global positioning system (GPS) instrument (Garmin eTrex 30) and leaf tissues collected. We harvested approximately $100 \mathrm{~g}$ of healthy leaf tissues from each sampled tree and dried them in silica gel until DNA isolation. In total, we collected leaf tissues from 450 individual trees from the 15 populations.

\subsection{DNA isolation and microsatellite analysis}

Total genomic DNA was isolated from the dried leaf samples using the modified cetyltrimethylammonium bromide (CTAB) protocol as described by Hanaoka et al. (2013). The quality and quantity of the isolated DNA was determined through NanoDrop spectrophotometer measurements and compared with $1 \%$ agarose gel electrophoresis. Ten polymorphic microsatellite loci isolated and characterized for $V$. tortilis (Omondi et al. 2015) were used to perform PCR analysis (Table 1). Polymerase chain reaction analysis was performed in a $6 \mu$ reaction volume using Qiagen Multiplex PCR Kit (Invitrogen) in a VeritiTM Thermal Cycler (Applied Biosystems). The PCR program followed the multiplex kit manufacturer's instructions, but we set the annealing temperature at $57^{\circ} \mathrm{C}$. The PCR fragments (products) were analyzed through capillary electrophoresis and scored against $600 \mathrm{Liz}$ internal size standard on an ABI 3500 genetic analyzer (Applied Biosystems). The genotypic data were captured using GeneMapper 5.0 software (Applied Biosystems, California, USA).

\subsection{Statistical analysis}

We tested the genotypic data for the presence of null alleles using Micro-Checker software (version 2.2.3) and screened for genotyping errors before statistical analysis. Genotypic frequencies for conformance to Hardy-Weinberg equilibrium (HWE) were assessed and linkage disequilibrium between makers verified prior to the estimation of genetic diversity parameters using Fisher's exact test available in Genepop v3.4 (Rousset 2008). We used sequential Bonferroni adjustments to determine significance level for all the tests with an initial $P$ level of 0.05 (Rice 1989). Genetic diversity was calculated per population and overall as the average number of alleles per locus $(A)$, the number of allele per population $\left(N_{\mathrm{A}}\right)$, the number of effective alleles per population $\left(A_{\mathrm{E}}\right)$, allelic richness $\left(A_{\mathrm{R}}\right)$, the observed proportion of heterozygotes $\left(H_{\mathrm{O}}\right)$, and the expected proportion of heterozygotes or gene diversity $\left(H_{\mathrm{E}}\right)$. The $F$ statistics $\left(F_{\mathrm{IS}}, F_{\mathrm{ST}}\right.$, and $\left.F_{\mathrm{IT}}\right)$ were determined using FSTAT (version 3.9.3.2) (Goudet 2002). The probability of the $F$ statistics being greater than zero was determined by bootstrap analysis using 1000 replications with a 95\% confidence interval.

The extent and significance of genetic differentiation among populations was determined by calculating $R_{\mathrm{ST}}$ (Slatkin 1995) using a stepwise mutation model (Kimura and Ohta 1978). Unbiased estimates of $R_{\mathrm{ST}}$ and their significance were estimated after 1000 bootstraps with $95 \%$ nominal confidence interval and permutation tests of 10,000 permutations (Lynch and Crease 1990), using $R_{\mathrm{ST}}$ Calc (version 2.2) (Goodman 1997). Standardized genetic differentiation was also determined through $G_{\text {st }}^{\prime}$ analysis as described by Hedrick (2005). Analysis of molecular variance (AMOVA) was calculated using Arlequin (version 1.1) (Schneider et al. 2000), in which significance level for the
Table 1 Genetic diversity parameters of the 10 nuclear microsatellite markers in 15 populations of $A$. tortilis in Kenya

\begin{tabular}{lllllllllll}
\hline Locus & $A$ & $A_{\mathrm{R}}$ & $H_{\mathrm{O}}$ & $H_{\mathrm{E}}$ & HWE & $F_{\text {null }}$ & $F_{\mathrm{IS}}$ & $F_{\mathrm{ST}}$ & $R_{\mathrm{ST}}$ & $N_{\mathrm{m}}$ \\
\hline kfat051 & 22 & 11.45 & 0.757 & 0.853 & $\mathrm{~ns}$ & 0.026 & 0.112 & 0.018 & 0.044 & 6.3 \\
kfat069 & 25 & 11.58 & 0.517 & 0.882 & $* * *$ & 0.042 & 0.414 & 0.032 & 0.038 & 4.2 \\
kfat083 & 21 & 10.05 & 0.553 & 0.801 & $* * *$ & 0.032 & 0.309 & 0.016 & 0.102 & 6.1 \\
kfat086 & 20 & 9.02 & 0.52 & 0.843 & $* *$ & 0.028 & 0.384 & 0.031 & 0.025 & 4.2 \\
kfat004 & 23 & 10.40 & 0.604 & 0.819 & $\mathrm{~ns}$ & 0.013 & 0.262 & 0.043 & 0.100 & 3.4 \\
kfat033 & 32 & 13.13 & 0.876 & 0.900 & $\mathrm{~ns}$ & 0.034 & 0.027 & 0.019 & 0.025 & 6.7 \\
kfat034 & 17 & 10.26 & 0.722 & 0.854 & $\mathrm{~ns}$ & 0.002 & 0.155 & 0.019 & 0.045 & 6.1 \\
kfat037 & 18 & 9.23 & 0.684 & 0.826 & $\mathrm{~ns}$ & 0.021 & 0.171 & 0.032 & 0.024 & 4.3 \\
kfat103 & 30 & 14.70 & 0.804 & 0.930 & $\mathrm{~ns}$ & 0.033 & 0.135 & 0.013 & 0.038 & 7.9 \\
kfat119 & 28 & 11.16 & 0.609 & 0.824 & $* *$ & 0.013 & 0.261 & 0.038 & 0.017 & 3.7 \\
Overall & 23.6 & 11.10 & 0.665 & 0.853 & $\mathrm{~ns}$ & 0.023 & 0.223 & 0.026 & 0.046 & 5.3 \\
\hline
\end{tabular}

$A$, the total number of alleles detected; $A_{\mathrm{R}}$, allelic richness; $H_{\mathrm{O}}$, observed heterozygosity; $H_{\mathrm{E}}$, expected heterozygosity; HWE, Hardy-Weinberg equilibrium; $F_{\text {null }}$, frequency of null alleles; $F_{\mathrm{IS}}$, inbreeding coefficient; $R_{\mathrm{ST}}$, coefficient of genetic differentiation among populations defined under the stepwise mutation model; $N_{\mathrm{m}}$, the number of migrants

Significance difference at $* * P<0.01 ; * * * P<0.001$ 
overall values was determined after 1023 permutations. Multilocus estimate of the effective number of migrants $\left(N_{\mathrm{m}}\right)$ between populations was calculated using the private allele method of Slatkin (1985).

Population structure was analyzed using Bayesian inference implemented in Structure (version 2.2) (Falush et al. 2007). The number of populations (genetic clusters) $(K)$ was set from 1 to 12 . After preliminary testing, the optimal number of groups $(K)$ was determined using a 500,000 burn-in period and 750,000 Monte Carlo Markov chains without prior information of the population of origin of each sampled individual and using the Locprior model in the admixture model. This model assumes correlated allele frequencies among subpopulations and is used without any prior information on clustering of samples. Simulations for each value of $K$ were repeated 20 times to provide stable probability estimates. The optimal number of groups was determined using the second-order rate of change approach (Evanno et al. 2005). Principal coordinate analysis (PCoA) implemented in GenAlEx (version 6.5) (Peakall and Smouse 2012) was also performed to identify the pattern of genetic relationship of the populations.

We evaluated the presence of phylogeographic structure using the SPAGeDi program (version 1.2) (Hardy and Vekemans 2002) through permutations of allele sizes among alleles within a single locus $\left(\mathrm{p} R_{\mathrm{ST}}\right)(10,000$ permutations). This analysis compares the observed $R_{\mathrm{ST}}$ value (before randomization) with the distribution of $\mathrm{p} R_{\mathrm{ST}}$ values obtained for all possible configurations of allele size permutations and indicates whether shifts in allele size resulting from stepwise mutations contribute to population differentiation (Hardy et al. 2003). We also investigated spatial genetic structure by testing for isolation by distance. A pairwise geographic distance matrix was calculated based on the latitude and longitude of each population, using the Geographic Distance Matrix Generator (version 1.2.3) (Ersts n.d. http:// biodiversityinformatics.amnh.org/open_source/gdmg). We tested the hypothesis that the populations are differentiated because of isolation by distance (Wright 1943) by correlating the pairwise $R_{\mathrm{ST}}$ matrix against the geographical distance matrix. Spearman's rank correlation coefficient was calculated and significance determined with 10,000 permutations using a Mantel procedure (Mantel 1967) available in Genepop (version 4.5.1) (Rousset 2008). To detect the presence of any geographic barrier among the populations, we used $F_{\mathrm{ST}}$, UNei's genetic distance and Nei's genetic distance matrices, and geographic positions of the populations to undertake barrier analysis using Barrier software (version 2.2) (Manni et al. 2004).

Possible population bottlenecks were evaluated following the procedure described by Omondi et al. (2010) using BOTTLENECK v1.2 program. Infinite alleles model (IAM), stepwise mutation model (SMM), and two-phase mutation model (TPM; using 95\% SMM) were applied. This approach compares observed and expected heterozygosities based on the observed number of alleles under mutation-drift equilibrium. Tests for mode shift (change in allele frequency distribution) were also applied.

Data availability The datasets generated and/or analyzed during the current study are available in the Dryad Digital Repository (Omondi et al. 2019) at https://doi.org/10.5061/dryad.6s82f20.

\section{Results}

\subsection{Microsatellite characteristics and diversity}

The summary statistics of the 10 microsatellite loci are given in Table 1. All the loci assayed were polymorphic, and a total of 236 alleles were identified. No significant frequency of null alleles $(r>0.05)$ was found in all the loci (Supplementary Table 1). However, significant deviations from HWE were detected in four loci (Table 1). In addition, no linkage disequilibrium was detected between any pairs of loci in all populations. The average number of alleles per locus was 23.6, ranging from 17 (kfat034) to 32 (kfat033). Gene diversity or expected heterozygosity $\left(H_{\mathrm{E}}\right)$ ranged from 0.801 to 0.930 , with an average of 0.853 , while mean observed heterozygosity $\left(H_{\mathrm{O}}\right)$ was 0.665 . Fixation index for all the 10 loci was greater than zero $\left(F_{\text {IS }}>0\right)$ for all the populations.

\subsection{Within-population genetic variation}

The genetic diversity indices for the $15 \mathrm{~V}$. tortilis populations are summarized in Table 2. Average observed heterozygosity $\left(H_{\mathrm{O}}\right)$ ranged from 0.557 (Kitui) to 0.743 (Isiolo), with a mean of 0.665 across all loci. Gene diversity $\left(H_{\mathrm{E}}\right)$ was lowest in Lokichogio population $\left(H_{\mathrm{E}}=0.810\right)$ and highest in Wamba population $\left(H_{\mathrm{E}}=0.876\right)$. The populations showed the presence of high allelic richness $\left(A_{\mathrm{R}}\right)$ with a mean of 12.4. The fixation index $\left(F_{\mathrm{IS}}\right)$ values were all positive and varied among the populations, ranging from 0.123 in Isiolo to 0.345 in Kitui.

\subsection{Population genetic structure}

The overall values of genetic differentiation were similar and significantly different from zero for standardized genetic differentiation value $\left(G_{\mathrm{st}}^{\prime}=0.214, P=0.000\right)$, infinite allelic model $\left(F_{\mathrm{ST}}=0.026, P=0.007\right)$, and stepwise mutation model $\left(R_{\mathrm{ST}}=0.032, P=0.004\right)$. The largest $F_{\mathrm{ST}}$ value was found between Magadi and Lokichogio populations $\left(F_{\mathrm{ST}}=0.048\right)$ while the least differentiation was between Kitui and Kajiado populations $\left(F_{\mathrm{ST}}=0.013\right)$. Hierarchical distribution of molecular variance revealed significant genetic differentiation among the groups. The analysis showed that $6 \%(P<0.05)$ of the total variation was among the populations, while $94 \%(P<0.05)$ was among the individuals within the populations (Table 3 ). 
Table 2 Geographical locations and descriptive statistics over all loci for each studied population of V. tortilis in Kenya

\begin{tabular}{llllllllll}
\hline Population & Latitude & Longitude & Altitude & $N$ & $A_{\mathrm{R}}$ & $N_{\mathrm{e}}$ & $H_{\mathrm{O}}$ & $H_{\mathrm{E}}$ & $F_{\mathrm{IS}}$ \\
\hline Kitui & -1.7256 & 38.0806 & 924 & 30 & 12.7 & 7.3 & 0.557 & 0.857 & 0.345 \\
Wamba & 1.1329 & 37.2381 & 1254 & 30 & 13.2 & 7.8 & 0.657 & 0.876 & 0.238 \\
Maua & 0.2551 & 38.1029 & 798 & 30 & 12.6 & 7.4 & 0.693 & 0.862 & 0.186 \\
Baringo & 0.6010 & 35.5665 & 1158 & 30 & 12.3 & 6.4 & 0.733 & 0.849 & 0.124 \\
Machakos & -1.6166 & 37.2453 & 1656 & 30 & 12.2 & 7.3 & 0.639 & 0.851 & 0.239 \\
Kajiado & -1.8688 & 36.7947 & 1645 & 30 & 13.6 & 7.6 & 0.622 & 0.860 & 0.270 \\
Mwingi & -0.9041 & 38.1529 & 830 & 30 & 12.4 & 7.4 & 0.693 & 0.858 & 0.183 \\
Magadi & -1.8271 & 36.2274 & 614 & 30 & 11.9 & 6.4 & 0.617 & 0.817 & 0.233 \\
Marsabit & 2.1583 & 37.8750 & 961 & 30 & 12.1 & 7.3 & 0.690 & 0.874 & 0.198 \\
Kakuma & 3.6361 & 35.0343 & 707 & 30 & 11.4 & 6.7 & 0.702 & 0.832 & 0.146 \\
Katiru & 2.2669 & 35.4774 & 735 & 30 & 13.2 & 6.8 & 0.659 & 0.844 & 0.208 \\
Lokichogio & 4.2054 & 34.3453 & 642 & 30 & 10.3 & 5.6 & 0.617 & 0.810 & 0.211 \\
Voi & -3.4024 & 38.5486 & 585 & 30 & 12.5 & 6.8 & 0.653 & 0.854 & 0.223 \\
Isiolo & 0.2768 & 37.7702 & 1341 & 30 & 13.8 & 7.3 & 0.743 & 0.861 & 0.123 \\
Bura & -1.1885 & 39.9164 & 96 & 30 & 11.3 & 6.2 & 0.697 & 0.844 & 0.166 \\
Overall & & & & 30 & 12.4 & 7.0 & 0.665 & 0.850 & 0.206 \\
\hline
\end{tabular}

$N$, sample size; $A_{\mathrm{R}}$, allelic richness; $N_{\mathrm{e}}$, the number of effective alleles; $H_{\mathrm{O}}$, observed heterozygosity; $H_{\mathrm{E}}$, expected heterozygosity; $F_{\text {IS }}$, inbreeding coefficient
Results of the model Structure using the delta $K$ criterion are shown in Figs. 2 and 3. The log likelihood revealed by the structure analysis for the two models showed the optimum value to be $2(K=2)$; however, significant values were also observed at $K=3$ and $K=4$. The maximum ad hoc measure $(\Delta K)$ was found to be $K=2$; however, this value was not very different from those of $K=3$ and $K=4$ (Fig. 2), which indicated that the entire $V$. tortilis population in Kenya can be grouped into two major clusters with other subgroups.

With $K=2$, we consistently got the same population structure for 20 independent runs. Based on the membership fractions, the individuals with the membership probability $>80 \%$ were assigned to the corresponding subgroups with others categorized as admixture (Figs. 3 and 4).

The cluster associations among individual trees of the 15 populations determined by the PCoA calculated based on Nei's genetic distance are presented in Fig. 5. In this analysis, Baringo population appears to be isolated from the other populations within its group. The other group also shows formation of three subgroups. The principal coordinates (1 and 2) accounted for $41 \%$ and $17.3 \%$ of the total variation, respectively. The average estimate of gene flow among populations $\left(N_{\mathrm{m}}\right)$ was 5.3 .

A phylogeographic signal was detected with permutation procedures in the total sample $\left[R_{\mathrm{ST}}\right.$ of 0.032 versus $\mathrm{p} R_{\mathrm{ST}}$ (permuted) of $0.002, P=0.0000]$. In addition, Nei's pairwise genetic distance ranged from 0.054 (Kitui-Kajiado) to 0.418 (Magadi-Kakuma). Average Nei's unbiased genetic distance $(0.229)$ was moderate, an indication of population divergence. The correlation between the pairwise $R_{\mathrm{ST}}$ matrix and the geographical distance for the pairwise comparisons among the 15 populations (Fig. 6) revealed the presence of isolation by distance, among the populations $\left(R^{2}=0.3527, P<0.001\right)$. Furthermore, barrier analysis detected a geographic barrier separating the populations into two main groups as revealed by the structure and cluster analyses (Fig. 7).

\subsection{Population bottleneck}

The bottleneck comparison between the observed and expected heterozygosities under a mutation-drift model using the Wilcoxon signed-rank test found none of the populations
Table 3 Analysis of molecular variance (AMOVA) among and within the 15 natural populations of $V$. tortilis in Kenya based on 10 nuclear microsatellite loci

\begin{tabular}{llllll}
\hline $\begin{array}{l}\text { Source of } \\
\text { variation }\end{array}$ & $\begin{array}{l}\text { Degrees of } \\
\text { freedom }\end{array}$ & $\begin{array}{l}\text { Sum of } \\
\text { squares }\end{array}$ & $\begin{array}{l}\text { Mean } \\
\text { squares }\end{array}$ & $\begin{array}{l}\text { Percentage of variance } \\
(\%)\end{array}$ & $\begin{array}{l}P \\
\text { value }\end{array}$ \\
\hline $\begin{array}{c}\text { Among } \\
\text { populations }\end{array}$ & 14 & $49,299.944$ & 3521.425 & 6 & 0.001 \\
$\begin{array}{c}\text { Within } \\
\text { population }\end{array}$ & 885 & $643,182.687$ & 726.760 & 94 & 0.001 \\
Total & 899 & $692,482.631$ & - & 100 & - \\
\hline
\end{tabular}




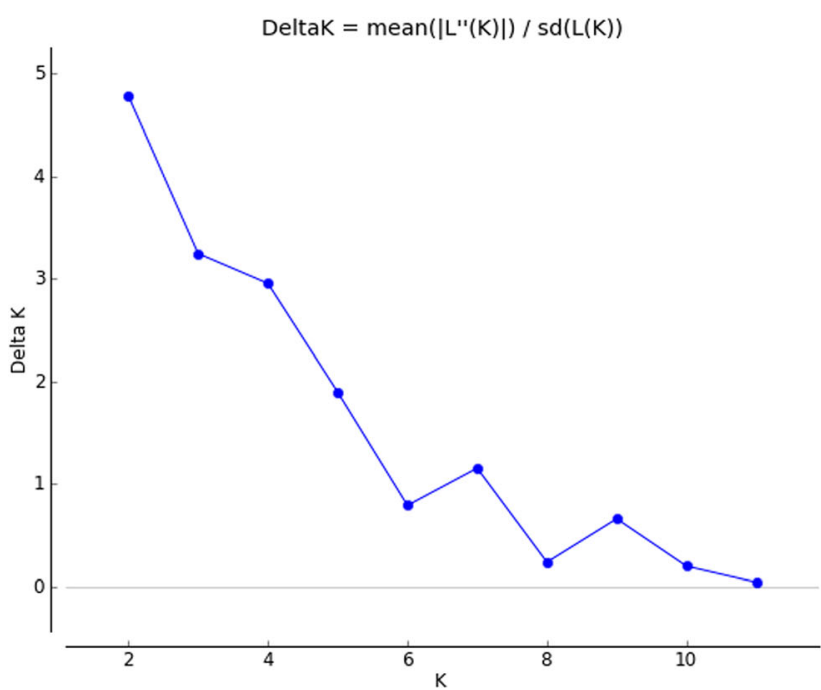

Fig. 2 a Estimation number of genetic clusters using $\Delta K$ values for $K$ ranging from 1 to 12 using the method proposed by Evanno et al. (2005). b Log likelihood of the data $(n=450), L(\mathrm{~K})$, as a function of $K$ (the

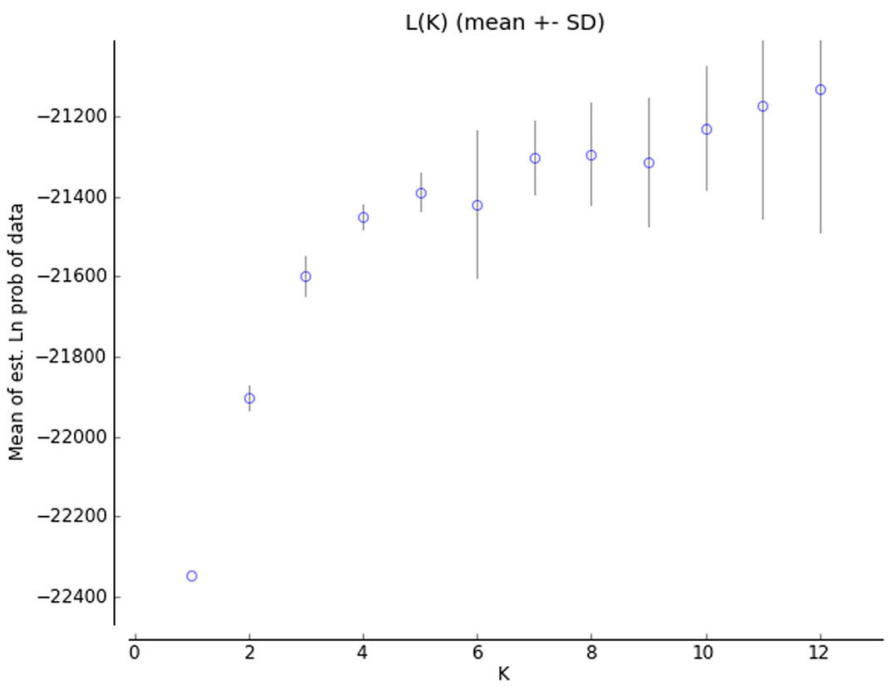

number of groups used to stratify the sample). For each $K$ value, 20 independent runs were considered and data were averaged over the replicates
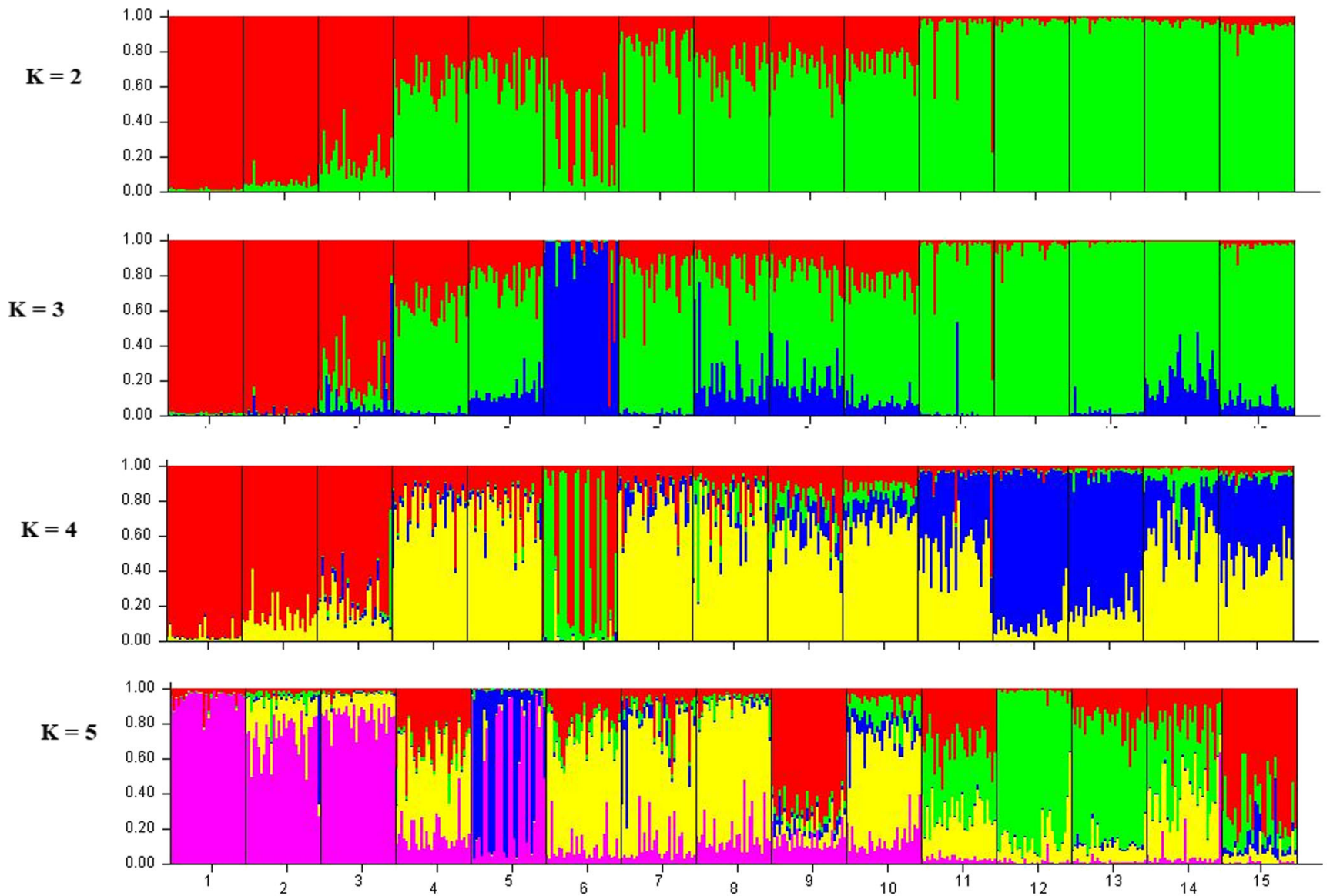

Fig. 3 Bayesian approach model-based estimation of population structure $(K=2, K=3$, and $K=4)$ of the 450 trees from the 15 populations of $V$. tortilis in Kenya genotyped at 10 nuclear microsatellite loci. Each line represents a single tree, with color representing the proportion of ancestry derived from each group. Gray lines indicate the population divisions (1, Lokichogio; 2, Kakuma; 3, Katiru; 4, Marsabit; 5, Wamba: 6, Baringo; 7, Isiolo; 8, Maua; 9, Mwingi; 10, Bura; 11, Kitui; 12, Machakos; 13, Kajiado; 14, Magadi; 15 , Voi) 
Fig. 4 Geographic distribution of assignment results of the

Structure $(K=2)$ analysis. The size of pies is proportional to the number of individuals sampled, and the colors correspond to clusters
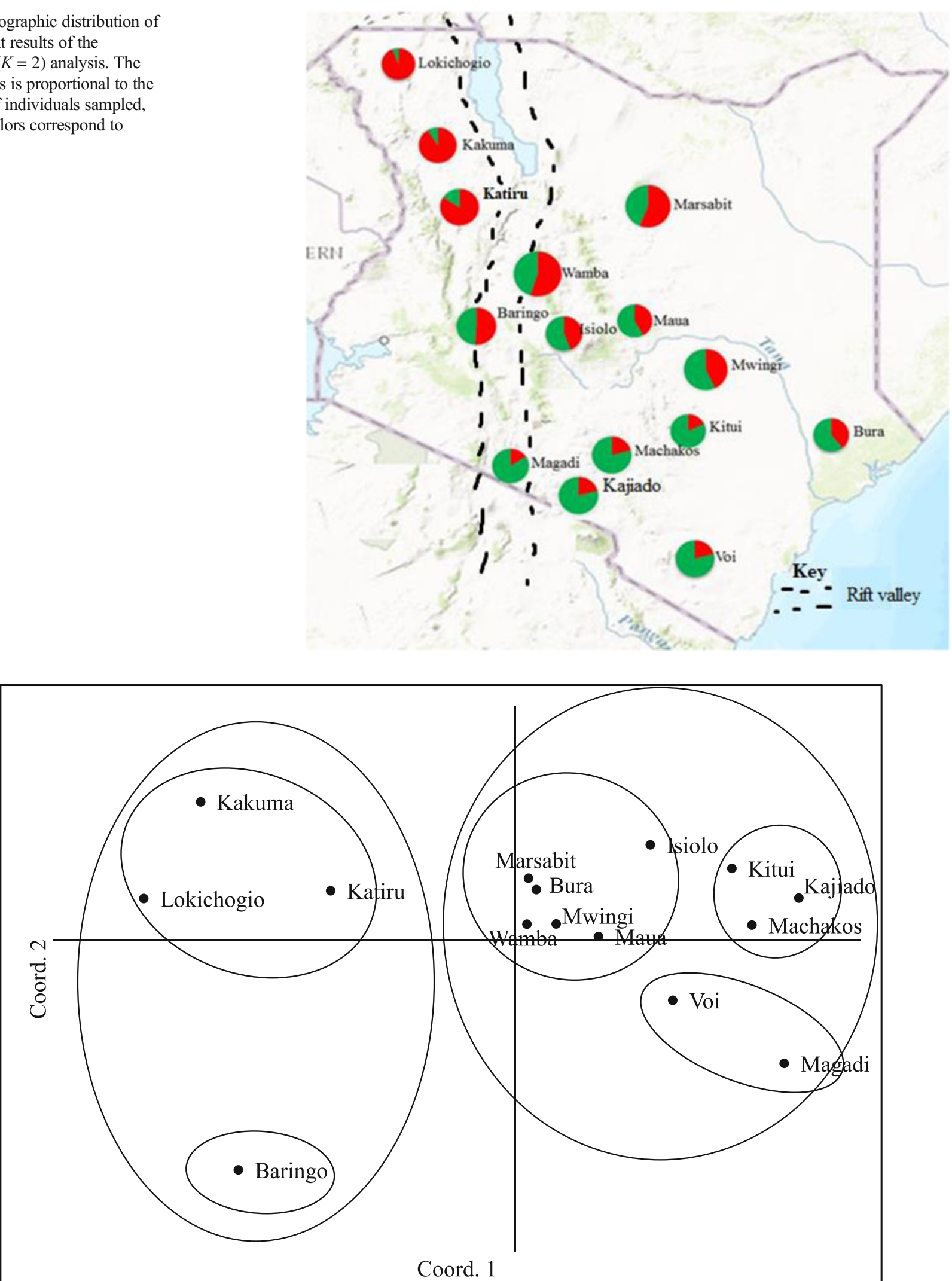

Coord. 1

Fig. 5 Principal coordinate analysis (PCoA) bit plot based on 10 nuclear microsatellite loci showing the clustering of the 15 natural populations of $V$. tortilis in Kenya 


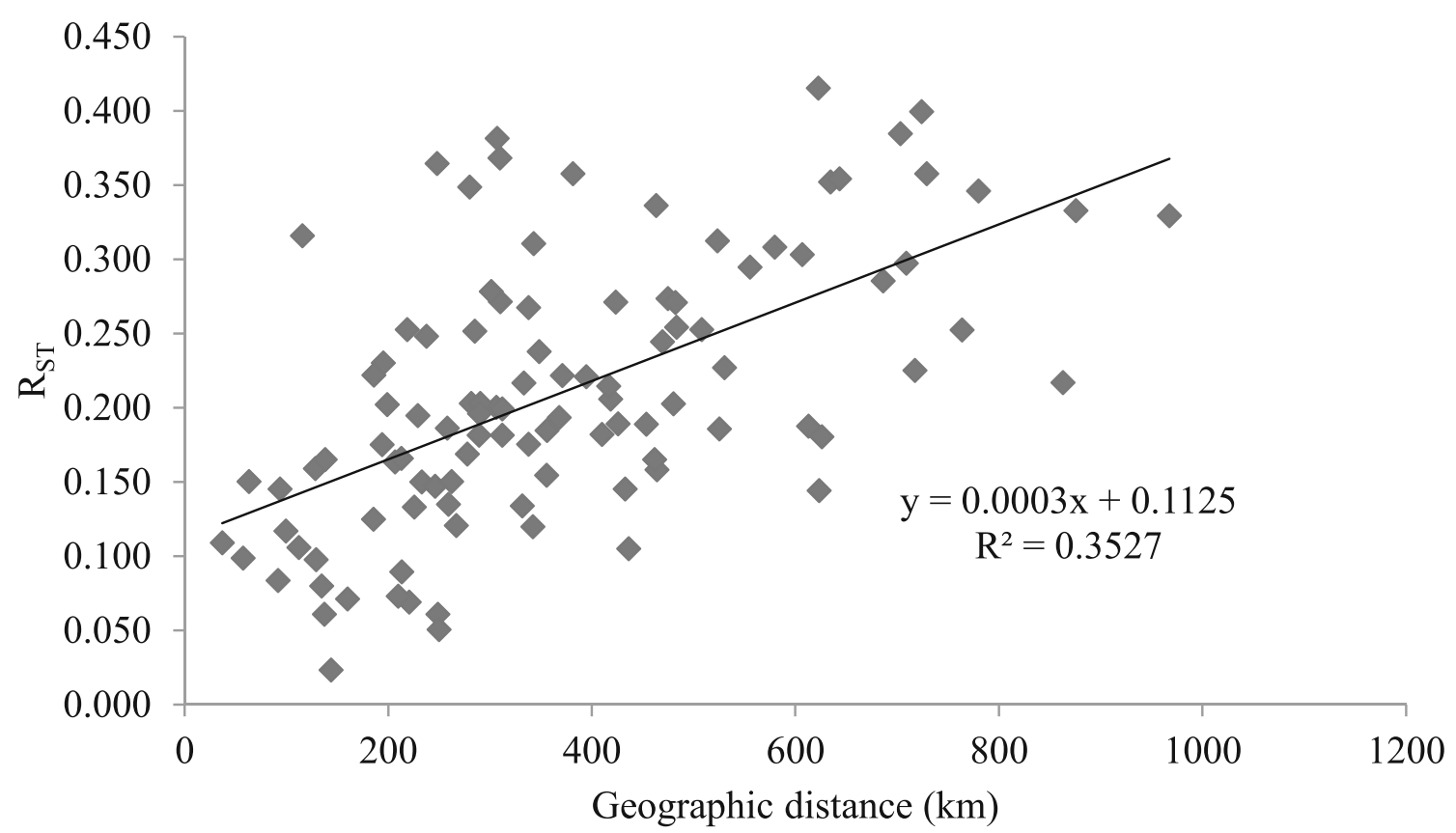

Fig. 6 The relationship between pairwise $R_{\mathrm{ST}}$ values and pairwise geographical distance in $V$. tortilis populations in Kenya

deviating significantly from mutation-drift equilibrium $(P>$ $0.05)$ under all the mutation model's assumptions. All populations showed normal L-shape distribution of rare allele frequencies under mode-shift test.

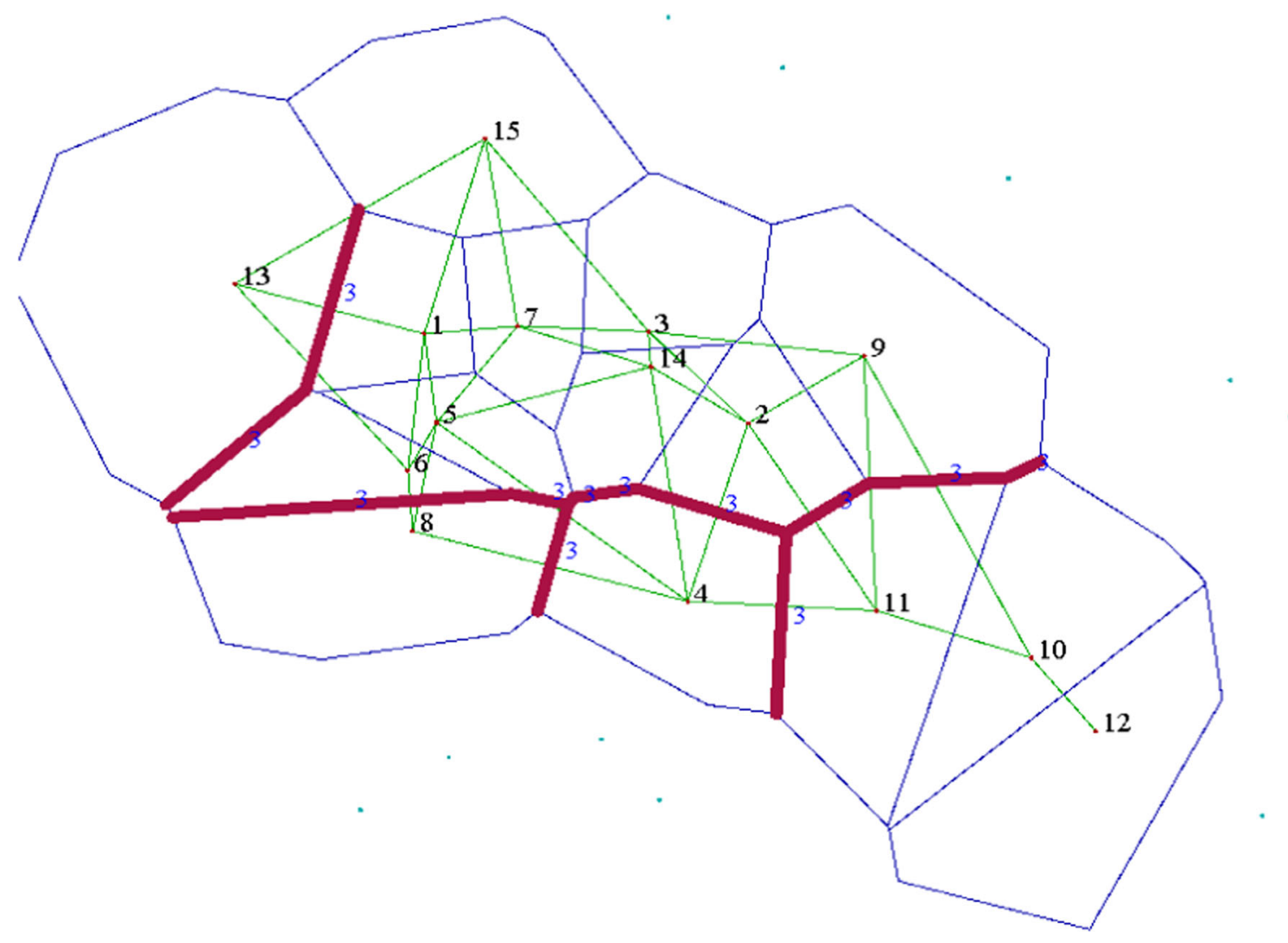

Fig. 7 Barrier analysis of the 15 natural populations of V. tortilis in Kenya 


\section{Discussion}

\subsection{Genetic diversity}

The results of HWE, LD, and null allele frequency analyses indicate that the microsatellite loci we used in the present study are reliable and robust and could be used successfully to assess genetic diversity and population structure in $V$. tortilis. This means that our results can be interpreted with high levels of confidence.

Overall, results confirm our hypothesis of the presence of a high level of genetic diversity in the Kenyan population of $V$. tortilis. This is evident from the estimates of diversity indices such as allelic richness $\left(A_{\mathrm{R}}=12.4\right)$ and mean gene diversity $\left(H_{\mathrm{E}}=0.850\right)$. These high values of genetic diversity may be attributed to the demographic history of the species and its spatial distribution patterns. Generally, long-lived tree species with wide geographic distribution like $V$. tortilis are usually known to exhibit high levels of genetic diversity (Omondi et al. 2016; Vendramin et al. 2008; Hamrick et al. 1992). Similar results have been reported in many tropical tree species especially those with outbreeding mating systems and long-distance gene flow patterns. Indeed, $V$. tortilis is such a long-lived species, with a presumed long-distance gene flow and genetically self-incompatible mating patterns, providing opportunities for high levels of genetic diversity. In addition, habitat condition is suggested to influence a species level of genetic diversity. In such case, high proportions of gene diversity are expected in species colonizing heterogeneous habitats (such as dryland ecosystems), probably for adaptation purposes (Wang et al. 2014).

The sub-Saharan habitat where V. tortilis is majorly found is relatively heterogeneous, and for tree species to adapt and survive is such diverse and harsh climatic conditions, commensurate genetic diversity is imperative. Perhaps, the heterogeneity of the habitat may be one of the reasons for the high level of gene diversity and for the large number of effective alleles $\left(N_{\mathrm{e}}=7.0\right)$ found in the $V$. tortilis populations. Such diversity provides the species with adaptive potential for survival and could be useful in improvement programs. Furthermore, maintenance of genetic variation for the species is important because future evolutionary adaptation depends on the existence of genetic variation. Such genetic diversity therefore needs to be conserved. Similar conclusion was suggested for Prunus sibirica, a species with wide spatial distribution in heterogeneous dryland of China (Wang et al. 2014). No genetic study that works on $V$. tortilis has been reported using microsatellite markers; however, a comparable high level of genetic diversity was found using RAPD markers in the Negev Desert by Shrestha et al. (2002). Our results further corroborate earlier reports of high genetic diversity within $V$. tortilis using morphological analysis by El Ferchichi et al. (2009) and El Ayadi et al. (2011) in Tunisia and Morocco, respectively. The level of genetic diversity found in the present study also conforms to high diversity that has been reported for other species within the same family with wide distribution range in similar ecosystem such as Senegalia senegal (Chiveu et al. 2008; Omondi et al. 2010; Odee et al. 2012). Lower genetic diversity was, however, evident in Lokichogio population, which is located along the Kenya-South Sudan boarder. This population may have suffered reduced genetic diversity through overexploitation that has been witnessed in these areas in the recent past due to fuelwood collection for use in the nearby refugee camp at Kakuma. Unprecedented harvesting and utilization of tree products within this population may have led to elimination of important rear alleles, and some species may have suffered genetic drift. This means that populations with low genetic diversity such as Lokichogio should be protected from further deterioration through detailed conservation program. In the same manner, populations with high genetic diversity should also be conserved to avoid similar losses. Reduced genetic diversity due to habitat degradation has also been reported for S. senegal (Omondi et al. 2016).

\subsection{Heterozygote deficit}

Our study revealed a strong heterozygote deficit in all populations, and high values of $F_{\text {IS }}$, particularly in Kitui population. Since analysis did not detect significant frequency of null allele in these populations, such deficiencies may be elucidated by two explanations. The first possible reason may be the occurrence of the Wahlund effect, which happens when a substructured population with varying allelic frequencies is treated as one entity (Hartl and Clark 2007). During our sampling and leaf tissue collection, large areas were covered in many of the populations that may have actually contained subpopulations within the larger population. The average distance coverage within each population in this study was about $16 \mathrm{~km}$ with individual population such as Kitui spanning over $20 \mathrm{~km}$ wide. The sampling may have erroneously included several discrete populations with varying allelic frequencies into one. In this case, the presence of subpopulations may have promoted differentiated reproductive units within the population hampering random mating. In this case, the occurrence of sympatric but differentiated populations of $V$. tortilis in our samples may have remained undetected during sampling. The second explanation would be limited gene flow patterns where genetically related individuals are clustered around the mother tree and are freely mating with one another. Limited gene flow may also be promoted by the pollinators' behavior mostly in cases where population density is low and the pollinators' activity remain localized within a particular cluster. However, the limited gene flow theory may be unlikely for $V$. tortilis. The species is pollinated mainly by bees that can move long distances. In addition, the species seeds are 
dispersed to longer distances by livestock that move long distances in search of pasture and water (Andersen et al. 2016). Nonetheless, mating among close relatives cannot be completely overruled. This is simply because seed dispersal through gravity or propulsion has also been suggested for $V$. tortilis, hence clusters of regularly mating close relatives are highly probable (Orwa et al. 2009). Of importance is also the feeding behavior of the dispersal ungulates. The ungulates sometimes feed under one tree for long duration, collecting much seeds from few trees, which may be deposited at one point, leading to a cluster of closely related individuals. This hypothesis may corroborate the earlier findings of Babikir and Ismail (1986) who reported restricted seed dispersal patterns in A. tortilis in Qatar. Further studies, however, are required to examine the mating system and gene flow patterns in V. tortilis to eliminate the hypothesis of self-pollination and ascertain the assumption of mating among relatives. Considering the two theories, the Wahlund effect is the most probable explanation for the reduced heterozygosities in the populations.

\subsection{Genetic structure}

Our study reveals significant genetic differentiation in the Kenyan population of $V$. tortilis $\left(F_{\mathrm{ST}}=0.026, P=0.007\right.$; $\left.G_{\text {st }}^{\prime}=0.214 ; R_{\mathrm{ST}}=0.032, P=0.004\right)$. Despite the differentiation, the large number of immigrants per generation $\left(N_{\mathrm{m}}=\right.$ 5.3) was detected, enhancing genetic connectivity among the populations. However, due to the hyper-variability of the microsatellite markers used in the current study, the $N_{\mathrm{m}}$ value may have been overestimated. Genetic structure is usually affected by several factors including population size, breeding systems, pollen and seed dispersal, genetic drift, natural selection, and evolutionary history (Hamrick and Godt 1990; Wu et al. 2015). The Bayesian analysis of $V$. tortilis defined two groups and provided clear indications of probable genetic divergence among the populations from the eastern and western parts of the Gregorian Rift Valley (Fig. 2). The AMOVA also showed that these two groups of populations are genetically differentiated $(6.0 \%, P=0.001)$ (Table 3$)$. These findings may reflect the limited spatial patterns of gene dispersal between the groups due to physical barrier; however, recent gene flow patterns may be bridging the gap as shown in the admixed ancestry of many individuals during structure analysis. Similar east-west genetic differentiation has been found in many other plants and animal species (Aoki et al. 2014 and the references therein). This finding is a key in laying strategy for conservation and breeding programs by focusing only on few populations from the two groups. The present results indicate that there are two major lineages of the nuclear genome in $V$. tortilis defined by the occurrence of the Gregorian Rift Valley, dividing the populations into two groups. This is corroborated by the barrier analysis that suggests the presence of a barrier similar to the direction of the Rift Valley. Populations found on the eastern side of the rift formed one group, while populations found on the western side formed another group. The significant role of the Gregorian Rift Valley in defining genetic lineages of tree species has been suggested for S. senegal in Kenya by Omondi et al. (2010). The present finding shows that the east-west groups may have been separated for an extended period of time and suggests the likely existence of refugia in the eastern group. Similar inference was observed on the genetic structure of Japanese broadleaved species which exhibited an east-west differentiation (Aoki et al. 2014). The major division in the present study was also confirmed through PCoA that differentiated the populations into two major groups; however, this analysis also revealed evidence of smaller subgroups within the major clusters (Fig. 5). Although the Structure analysis revealed $K=2$ as the best number of groups, some subgroups could be evident when $K=3, K=4$, and $K=5$ were considered (Fig. 3), which may explain the occurrence of subgroups in PCoA analysis. The eastern cluster differentiated into three smaller groups, which generally reflected the geographic distance among these populations. These differences are actually evident in the barrier, phylogeographic structure, and isolation by distance analysis that revealed a positive and significant correlation among genetic and geographic distances. This therefore means that careful consideration should be made while selecting populations for improvement and conservation programs. In this case, far apart populations should be selected.

Despite using different approaches and markers, similar differentiation in $V$. tortilis has been reported in earlier studies (El Ayadi et al. 2011). Larger genetic differentiation (59\% of diversity was attributed to among populations) than the one reported in the present study (6\%) was also reported in the Negev Desert in Israel (Shrestha et al. 2002). The structuring of $V$. tortilis in the Negev Desert was, however, attributed to the historical colonization of the species in the region and limited gene flow among the populations. Small livestock have been shown to play a significant role in seed dispersal in most dryland tree species, especially the palatable acacias (Andersen et al. 2016). These animals may have promoted the structuring of the $V$. tortilis population in Kenya into the two clusters. Historically, livestock movement patterns have not allowed the east-west migration due to community rivalry and cattle rustling common among these boarders. These occurrences generally promote north-south movement, which may have enhanced genetic homogeneity within the two groups rather than between them. This hypothesis may be validated by the Baringo population, which appeared slightly differentiated from the three northern populations of $V$. tortilis generally, because there are restrained livestock movements in that direction, hence isolating Baringo population. However, the barrier analysis suggests the presence of a geographic barrier. Shrestha et al. (2002) also suggested the limited activity of wild herbivores and restricted movement of livestock as the 
major factors that contributed to the high level of $V$. tortilis population differentiation in the Negev Desert. This finding corroborates the significance of zoogamy in $V$. tortilis gene flow, which is reported by Andersen et al. (2016).

\subsection{Population bottlenecks}

The bottleneck comparison between the observed and expected heterozygosities under a mutation-drift model using the Wilcoxon signed-rank test found none of the populations deviating significantly from mutation-drift equilibrium $(P>$ 0.05 ) under all the mutation model's assumptions. All populations showed normal L-shape distribution of rare allele frequencies under mode-shift test. This is an indication that the anthropogenic disturbances witnessed within the species distribution have not left any population bottleneck signature or the disturbances may be recent. Furthermore, high gene flow values found in the present study suggest that there is genetic connectivity among the population that would prevent genetic drift. No sign of population bottleneck despite heightened human disturbances has also been reported for other acacia species such as $S$. senegal with similar distribution range and dispersal mode (Omondi et al. 2010, 2016). However, precautionary measures need to be taken to protect the populations from unsustainable utilization, more so to populations like Lokichogio, which has shown signs of reduced gene diversity. This can be achieved through development and implementation of sustainable management strategies that will take cognizance of the present genetic constitution and structure.

\section{Conclusion}

Our study tested the hypothesis that there would be high genetic diversity and absence of population differentiation in the Kenyan population of $V$. tortilis. The results have confirmed high genetic diversity; however, significant population structure has been revealed. The study suggests that mating systems, gene flow, and the occurrence of physical barrier within the species distribution range may have played a significant role in maintaining high genetic diversity and structuring of the population. This study further provides a proof that the species has been able to maintain effective population size to prevent the occurrence of genetic bottlenecks. The genetic diversity results presented opportunities for breeding and tree improvement for adaptation to both abiotic and biotic factors and improved productivity. Indeed, these results will be useful in the current breeding for drought tolerance program of the species by directing where selections should be focused. In addition, populations that are threatened by reduced gene diversity such as Lokichogio should be marked for conservation. Both the high level of genetic variation within populations and the isolation by distance suggest that in situ conservation strategies, like the creation of reserves, could be designed to preserve large areas to minimize the loss of diversity due to genetic drift and to conserve maximally the regional genotypic diversity. Conservation and sampling strategies for genetic improvement should take into account the determined gene pools of the species.

Acknowledgements We are grateful particularly to the Kenya Forestry Research Institute (KEFRI) Biotechnology and Forest Tree Breeding Center (FTBC) molecular laboratory staffs for their support during the study. We are grateful to the directors of the two institutes for supporting the study.

Author's Contribution Stephen F. Omondi designed the study, performed the laboratory analysis, analyzed the data, and wrote the manuscript. Joseph M. Machua contributed in reviewing and writing the manuscript. Gabriel M. Muturi contributed in supervising the work and paper reviewing. John M. Gicheru performed the laboratory analysis and paper reviewing while So Hanaoka contributed in designing the study, supervising the work, and reviewing and writing the manuscript.

Funding This study was funded under the bilateral collaboration between the Kenya Forestry Research Institute (KEFRI) and Forest Tree Breeding Center (FTBC) and Forestry and Forest Products Research Institute (FPRRI) of Japan under the KEFRI/JICA Project on the development of drought-tolerant trees for adaptation to climate change in drylands of Kenya.

\section{Compliance with ethical standards}

Conflict of interest The authors declare that they have no conflict of interest.

\section{References}

Abdallah F, Noumi Z, Touzard B, Ouled Belgacem A, Chaieb M (2008) The influence of Acacia tortilis (Forssk.) subsp. raddiana (Savi) and livestock grazing on grass species composition, yield and soil nutrients in arid environments of south Tunisia. Flora 203:116-125

Abdelrahman, HF (2007) Ecotypes or genotypes? The status of the currently recognized infraspecific taxa of Acacia tortilis (Forssk.) Hayne growing in the Red Sea Hills, Sudan and Egypt. PhD thesis, University of Bergen

Abdelrahman HF, Krzywinski K (2008) Environmental effects on morphology of Acacia tortilis group in the Red Sea Hills, North-Eastern Sudan and South-Eastern Egypt. Forest Ecol Manag 255(1):254 263

Aldrich PR Hamrick JL (1998) Reproductive dominance of pasture trees in a fragmented tropical forest mosaic. Science 281:103-105

Allen DJ (2007) A traveler's guide to the wild flowers and common trees of east Africa. Camerapix Publishers International, Singapore

Andersen GL, Krzywinski K (2007) Longevity and growth of Acacia tortilis; insights from ${ }^{14} \mathrm{C}$ content and anatomy of wood. BMC Ecol 7:4. https://doi.org/10.1186/1472-6785-7-4

Andersen GL, Krzywinski K, Gjessing HK, Pierce RH (2016) Seed viability and germination success of Acacia tortilis along land-use and aridity gradients in the Eastern Sahara. Ecol Evol 6(1):256-266

Aoki K, Ueno S, Kamijo T, Setoguchi H, Murakami N et al (2014) Genetic differentiation and genetic diversity of Castanopsis (Fagaceae), the dominant tree species in Japanese broadleaved evergreen forests, revealed by analysis of EST-associated 
microsatellites. PLoS One 9(1):87429. https://doi.org/10.1371/ journal.pone. 0087429

Babikir AAA, Ismail AMA (1986) Pattern in the distribution of Acacia tortilis (Forsk.) Hayne. GeoJournal 12(4):403-407

Bawa KS, Seidler R (1998) Natural forest management and conservation of biodiversity in tropical forests. Conserv Biol 12(1):46-55

Berchem J (1994) Aspects of traditional and potential utilization of the indigenous vegetation of Northern East Africa: a contribution of ethnobotany to self-reliant and people-oriented development at the Horn of Africa. OMIMEE Intercultural Publishers, Cologne, Germany, pp 35-40

Chiveu CJ, Dangasuk OG, Omunyin ME, Wachira FN (2008) Genetic diversity in Kenyan populations of Acacia senegal (L) Willd revealed by combined RAPD and ISSR markers. Afr J Biotechnol 7(14):2333-2340

Dick CW (2001) Genetic rescue of remnant tropical trees by an alien pollinator. Proc R Soc Lond B Biol Sci 268:2391-2396

El Ayadi F, Aabd NA, El-Finti A, Msanda F, Baniaameur F, El-Mousadik A (2011) Genetic variability of wild provenances of Acacia tortilis ssp. raddiana (Savi) Brenan in south of Morocco. Asian J Plant Sci 10:43-51

El Ferchichi HO, Walker DJ, Khouja ML, Correal E (2009) Diversity analysis of Acacia tortilis (Forsk.) Hayne ssp. raddiana (Savi) Brenan (Mimosaceae) using phenotypic traits, chromosome counting and DNA content approaches. Genet Resour Crop Evol 56(7):1001-1010

Ersts PJ (n.d.) (Internet) Geographic Distance Matrix Generator (version 1.2.3). American Museum of Natural History, Center for Biodiversity and Conservation. Available from http:// biodiversityinformatics.amnh.org/open source/gdmg. Accessed 20 July 2017.

Evanno G, Regnaut S, Goudet J (2005) Detecting the number of clusters of individuals using the software STRUCTURE: a simulation study. Mol Ecol 14:2611-2620

Falush D, Stephens M, Pritchard JK (2007) Inference of population structure using multilocus genotype data: dominant markers and null allele. Mol Ecol Notes 7:574-578

Goodman SJ (1997) RST Calc: a collection of computer programs for calculating estimates of genetic differentiation from microsatellite data and determining their significance. Mol Ecol 6:881-885

Goudet J (2002) FSTAT, a program to estimate and test gene diversities and fixation indices (version 2.9.3.2). Free available at http://www. unil.ch/izea/softwares/fstat.html. Accessed 15 Jan 2018

Hamrick JL, Godt MJW (1990) Allozyme diversity in plant species. In: Brown AHD, Clegg MT, Kahler AL, Weir BS (eds) Plant population genetics, breeding, and germplasm resources. Sinauer, Sunderland, pp 43-63

Hanaoka S, Omondi SF, Machua J (2013) Basic molecular techniques for tree breeding - experimental protocols. Sankeisha Co. Ltd, Aichi, Japan

Hardy OJ, Vekemans X (2002) SPAGeDi: a versatile computer programme to analyse spatial genetic structure at the individual or population levels. Mol Ecol Notes 2:618-620

Hardy OJ, Charbonnel N, Fréville H, Heuertz M (2003) Microsatellite allele sizes: a simple test to assess their significance on genetic differentiation. Genetics 163:1467-1482

Hartl DL, Clark AG (2007) Principles of population genetics, 4th edn. Sinauer Associates Inc, Sunderland, MA, USA, p 652

Hedrick PW (2005) A standardized genetic differentiation measure. Evolution, 59:1633-1638

Hines DA, Eckman K (1993) Indigenous multipurpose trees of Tanzania: uses and economic benefits for people. FAO, Rome

Hobbs JJ, Krzywinski K, Andersen GL et al (2014) Acacia trees on the cultural landscapes of the Red Sea Hills. Biodivers Conserv 23(12): 2923-2943. https://doi.org/10.1007/s10531-014-0755-x
Kennenni L (2008) Geography and phytosociology of Acacia tortilis in the Sudan. Afr J Ecol 29(1):1-10. https://doi.org/10.1111/j.13652028.1991.tb00814.x

Kimura M, Ohta T (1978) Stepwise mutational model and distribution of allelic frequencies in a finite population. Proc Natl Acad Sci U S A 75:2868-2872

Kyalangalilwa B, Boatwright JS, Daru BH, Maurin O, Van der Bank M (2013) Phylogenetic position and revised classification of Acacia s.l. (Fabaceae: Mimosoideae) in Africa, including new combinations in Vachellia and Senegalia. Bot J Linn Soc 172:500-523

Lamb D, Erskine PD, Parrotta JA (2005) Restoration of degraded tropical forest landscapes. Science 310:1628-1632

Le Floćh E, Grouzis M (2003) Acacia Raddiana, a multipurpose tree of arid regions. Book: Tree of desert Acacia raddiana. IRD Publication, Paris, ISBN: 2-7099-1522-7, pp 21-58

Luckow M (2005) Tribe Mimoseae. In: Lewis G, Schrire B, Mackinder B, Lock M (eds) Legumes of the world. Royal Botanic Gardens, Kew, pp 163-183

Lynch M, Crease TJ (1990) The analysis of population survey data on DNA sequence variation. Mol Biol Evol 7:377-394

Mantel N (1967) The detection of disease clustering and a generalized regression approach. Cancer Res 27:209-220

Maundu M, Tangnas B (2005) Useful trees and shrubs for Kenya. World Agroforestry Center, Nairobi, Kenya

Nason JD, Hamrick JL (1997) Reproductive and genetic consequences of forest fragmentation: two case studies of neotropical canopy trees. J Hered 88(4):264-276

Odee DW, Telford A, Wilson J, Gaye A, Cavers S (2012) Plio-Pleistocene history and phylogeography of Acacia senegal in dry woodlands and savannahs of sub-Saharan tropical Africa: evidence of early colonisation and recent range expansion. Heredity 109:372-382

Omondi FS, Kireger E, Dangasuk GO, Chikamai B, Odee DW, Cavers S, Khasa DP (2010) Genetic diversity and population structure of Acacia senegal (L) Willd. in Kenya. Trop Plant Biol 3:59-70

Omondi SF, Machua J, Gicheru JM, Hanaoka S (2015) Isolation and characterization of microsatellite markers for Acacia tortilis (Forsk.) Hayne. Conserv Genet Resour 7(2):529-531

Omondi SF, Ongamo GO, Kanya JI, Odee DW, Khasa DP (2016) Genetic consequences of anthropogenic disturbances and population fragmentation in Acacia senegal. Conserv Genet 17(6):1235-1244. https://doi.org/10.1007/s10592-016-0854-1

Omondi SF, Machua J, Muturi GM, Gicheru JM, Hanaoka S (2019) Data from: Evidence of high genetic diversity and significant population structuring in Vachellia tortilis (Forsk.) Galasso \& Bonfi population in Kenya. Dryad [Dataset]. https://doi.org/10.5061/dryad.6s82f20 Accessed 08 Mar 2019

Orwa C, Muta A, Kindt R, Jamnads R, Anthony S (2009) Agroforestree database: a tree species reference and selection guide version 4.0. http://www.orldagrofrestry.org/sites/tredbs/tredatbase.asp. Accessed 06 Dec 2017

Peakall R, Smouse PE (2012) GenAlEx 6.5: genetic analysis in Excel. Population genetic software for teaching and research - an update. Bioinformatics 28:2537-2539

Primack RB (1993) Essentials of conservation biology. Sinauer Associates, Sunderland, Mass., U.S.A

Rice WR (1989) Analyzing tables of statistical tests. Evolution 43:223225

Roberts L, Stone R, Sugden A (2009) The rise of restoration ecology. Science 325:555

Romdhane SB, Nasr H, Samba-Mbaye R, Neyra M, Ghorbal MH, de Lajudie P (2006) Genetic diversity of Acacia tortilis ssp. raddiana rhizobia in Tunisia assessed by $16 \mathrm{~S}$ and $16 \mathrm{~S}-23 \mathrm{~S}$ rDNA genes analysis. J Appl Microbiol 100:436-445

Rousset F (2008) Genepop'007: a complete reimplementation of the Genepop software for Windows and Linux. Mol Ecol Resour 8: 103-106 
47 Page 14 of 14

Annals of Forest Science (2019) 76: 47

Schneider S, Roessli D, Excoffier L (2000) Arlequin: a software for population genetics data analysis. Genetics and Biometry Lab, Dept. of Anthropology, University of Geneva, Switzerland

Shrestha MK, Golan-Goldhirsh A, Ward D (2002) Population genetic structure and the conservation of isolated populations of Acacia raddiana in the Negev desert. Biol Conserv 108:119-127

Slatkin M (1985) Gene flow in natural populations. Annu Rev Ecol Syst $16: 393-430$

Slatkin M (1995) A measure of population subdivision based on microsatellite allele frequencies. Genetics 139:457-462

Tybirk K (1993) Pollination, breeding system and seed abortion in some African acacias. Bot J Linn Soc 112:107-137

United Nations Environment Management Group (UNEMG) (2011) Global drylands: a UN system-wide response. United Nations, United States

Van Coillie F, Delaplace K, Gabriels D, de Stet K, Ouessar M, Belgacem AO, Taamallah H, de Wulf R (2016) Monotemporal assessment of the population structure of Acacia tortilis (Forssk.) Haynes sp. raddiana (Savi) Brennan in Bu Hedma National Park, Tunisia: a terrestrial and remote sensing approach. J Arid Environ 129(2016): $80-92$

Wahbi J, Kaouther M, Lamia H, Mohsen H, Larbi KM (2013) Acacia tortilis (Fork) Haynes subs raddiana (Savi) in a North African pseudo-savanna: morphological variability and seed characteristics. Afr J Agric Res 8(21):2482-2492. https://doi.org/10.5897/AJAR11. 236
Wang Z, Kans M, Lu H, Gao J, Chang Z, Li Y, Wu R, Pang X (2014) High-level genetic diversity and complex population structure of Siberian apricot (Prunes sibirica L.) in China as revealed by nuclear SSR markers. PLo One 9(2):e87381

Whitmore TC (1997) Tropical forest disturbance, disappearance and pecries loss. In: Laurance WF, Bierregaard RO (eds) Tropical forest remnants: ecology, management, and conservation of fragmented communities. The University of Chicago Press, Chicago, pp 3-12

Winters G, Shklar G, Horol L (2013) Characterizations of microsatellite DNA markers for Acacia tortilis. Conserv Genet Resour 5:807-809

Wright S (1943) Isolation by distance. Genetics 28(2):114-138

Wu FQ, Shen SK, Chang XJ, Wang YH, Sun WB (2015) Genetic diversty and population structure of an extremely endangered species: the world's largest Rhododendron. AoB PLANTS 7:plu082. https:// doi.org/10.1093/aobpla/plu082

Young AG, Boyle T, Brown ADH (1996) The population genetic conequinces of habitat fragmentation for plants. Trends Ecol Evil 11: 413-418

Publisher's note Springer Nature remains neutral with regard to jurisdictional claims in published maps and institutional affiliations.

Springer

INA

SCIENCE \& IMPACT 